\title{
Significant limitations associated with the analysis of human plasma soluble CD36 performed by ELISA
}

\section{Analiza osoczowych stężeń CD36 metodą ELISA oraz jej ograniczenia}

\author{
Violetta Dziedziejko ${ }^{1}$, Natalia Pauli², Agnieszka Kuligowska ${ }^{1}$ Krzysztof Safranow ${ }^{1}$, Marta Goschorska ${ }^{1}$, \\ Dariusz Chlubek ${ }^{1}$, Monika E. Rać ${ }^{1 凶}$
}

${ }^{1}$ Pomorski Uniwersytet Medyczny w Szczecinie, Zakład Biochemii, Katedra Biochemii i Chemii Medycznej, al. Powstańców Wlkp. 72, 70-111 Szczecin Pomeranian Medical University in Szczecin, Department of Biochemistry

${ }^{2}$ Wielospecjalistyczny Szpital Wojewódzki w Gorzowie Wielkopolskim, Odział Kardiologii, ul. Dekerta 1, 66-400 Gorzów Wlkp.

County Hospital in Gorzów Wielkopolski, Department of Cardiology

$\triangle$ carmon12@gmail.com

\begin{abstract}
Introduction: Plasma $\mathrm{SCD} 36$ is generally considered to be a marker of macrophage activation and inflammation, accelerated fat accumulation in the vascular wall, and atherosclerosis. The objective of the study is to develop a methodology for sCD36 determination.

Materials and methods: The material for $\mathrm{sCD} 36$ determination by ELISA assays was collected from fasting blood samples from healthy cases.
\end{abstract}

Results: The study identified possible problems in sCD36 plasma concentration measurement. The presented data also suggested that the interrelationship of sCD36 and various metabolic stimuli can significantly affect $\mathrm{SCD} 36$ plasma concentration.

Conclusion: The ELISA assay can be used to determine sCD36 concentration in human plasma. Keywords: sCD36 determination; plasma; ELISA; methodology.

\begin{abstract}
ABSTRAKT
Wstęp: Badania wskazuja, że stężenie białka sCD36 w osoczu mogłoby być markerem aktywacji makrofagów i stanu zapalnego oraz przyspieszonej akumulacji lipidów w ścianie naczyniowej, które w rezultacie prowadzą do miażdżycy tętnic.

Celem badania było opracowanie wiarygodnej metodyki oznaczania sCD36.

Materiały i metody: Jako materiał do opracowania metodyki oznaczania stężenia sCD36 w osoczu testem ELISA posłużyły pobrane na czczo próbki krwi od losowo wybranych zdrowych
\end{abstract}

osób, które zgłosiły się na obowiązkowe badania kontrolne w Przychodni Medycyny Pracy.

Wyniki: Wykazano możliwe problemy w pomiarze stężenia sCD36 w osoczu metodą ELISA. Wskazano również, że interakcje sCD36 z innymi czynnikami mogą wpływać w szerokim zakresie na stężenie $\mathrm{sCD} 36 \mathrm{w}$ osoczu.

Wnioski: Uwzględniając pewne ograniczenia, test ELISA można wykorzystać do oznaczania stężenia sCD36 w osoczu ludzkim. Słowa kluczowe: oznaczanie stężenia sCD36; osocze; ELISA; metodyka.

\section{INTRODUCTION}

CD36 is a major receptor for the uptake of oxidized LDL [1]. It is a glycoprotein situated in plasma membranes of platelets, monocytes, macrophages, adipocytes and muscles [2,3]. The available data suggest $[4,5,6,7,8,9]$ that the monocyteto-macrophage differentiation by $\mathrm{CD}_{3} 6$ expression may play a critical role in the initiation and progression of atherosclerosis by facilitating the formation of lipid-engorged macrophage foam cells. The $C D 36$ gene is located on chromosome 7q11.2 [10]. The plasma circulating product of the $C D_{3} 6$ gene, soluble $C_{3} 6$ (sCD36), is not derived from proteolytic cleavage of the extracellular part of the $\mathrm{CD} 36$ protein [11], but may be present as the unbound protein in a peptide fraction or in microparticles shed from cells after being triggered by various stimuli or during cell apoptosis $[12,13]$. It has been proposed in some studies $[10,14]$ that $S C D 36$ could be a marker of macrophage activation and inflammation, accelerated fat accumulation in the vascular wall, and atherosclerosis. The analysis of sCD36 is currently hampered by the lack of widely accepted standardized methods of plasma $\mathrm{SCD} 36$ determination. Therefore, the study aims to develop a methodology for $\mathrm{s} C \mathrm{D} 36$ determination by ELISA assays.

\section{MATERIALS AND METHODS}

The material for sCD36 determination comprised 35 healthy subjects, 8 men and 27 women, older than 70 years, without accompanying diseases. The study complies with the principles 
of the Declaration of Helsinki and was approved by the local Institutional Ethics Committee (BN-001/162/04). Informed consent was obtained from participating subjects. Fasting blood samples were taken for sCD36 measurements.

EDTA-anticoagulated blood samples were centrifuged for 10 $\min$ at $4000 \mathrm{~g}$ and then stored at $-30^{\circ} \mathrm{C}$. Plasma concentrations of human antigen CD36 (also called platelet membrane glycoprotein IV) were measured, according to the manufacturer's instructions, with the use of ELISA kits, which is a commercially available enzyme-linked immunosorbent assay (EIAab, Wuhan EIAab Science Co., Ltd., China). All the samples were diluted $5000 \times$ with sample diluent. It was impossible to determine the concentration of $\mathrm{sCD}_{3} 6$ on the curve in this assay with lower dilution of the sample, thus only extrapolation was possible rather than accurate determination. The standard was reconstituted with $1.0 \mathrm{~mL}$ of sample diluent and set aside for $15 \mathrm{~min}$ with gentle agitation prior to making serial dilutions. This reconstitution produced a stock solution of $10.0 \mathrm{ng} / \mathrm{mL}$. The undiluted standard served as the high standard (10.0 ng/mL). The sample diluent served as the zero standard (0 $\mathrm{ng} / \mathrm{mL}$ ). A monoclonal antibody specific for $\mathrm{sCD} 36$ was pre-coated onto a microplate. Standards and samples were pipetted into the wells and any sCD36 present was bound by the immobilized antibody. This was followed by a 2-hour incubation at $37^{\circ} \mathrm{C}$. Detection reagents were diluted to the working concentration using assay diluent 1:100. After removing liquid from any unbound substances, a biotin-conjugated polyclonal antibody specific for sCD36 was added to the wells and again incubated for another $60 \mathrm{~min}$ at $37^{\circ} \mathrm{C}$. Following a wash to remove any unbound antibody-enzyme reagent, an avidin conjugated with Horseradish Peroxidase (HRP) solution was added to the wells. Wash buffer was warmed to room temperature and mixed gently. $30 \mathrm{~mL}$ of wash buffer concentrate was diluted into distilled water to prepare $750 \mathrm{~mL}$ of wash buffer. The wash process was repeated 3 times to remove any remaining wash buffer by decanting. After the last wash the plate was inverted and blotted with clean paper towels. In the next step, after washing away any unbound substances, a $90 \mu \mathrm{L}$ of substrate solution was added to the wells for $30 \mathrm{~min}$ at $37^{\circ} \mathrm{C}$. The substrate solution was TMB-tetramethylbenzidine. The colour development was stopped with $50 \mu \mathrm{L}$ of sulfuric acid. In each step of the procedure the total dispensing time for the addition of reagents to the assay plate did not exceed $10 \mathrm{~min}$. Absorbance was read at $450 \mathrm{~nm}$ with correction at $\lambda=630 \mathrm{~nm}$. We used an automated Microplate Reader ELX 808IU (Bio-Tek Instruments Inc). The results were analyzed using a quadratic curve fit. The calibration was performed with recombinant human CD36 in concentration range $0.15^{-10} \mathrm{ng} / \mathrm{mL}$.

\section{RESULTS AND DISCUSSION}

In our study the median plasma sCD36 concentrations with lower quartile $\left(Q_{1}\right)$ and upper quartile $\left(Q_{3}\right)$ was $19.0 \mu \mathrm{g} / \mathrm{mL}$ $\left(Q_{1}: 13.50 \mu \mathrm{g} / \mathrm{mL} ; \mathrm{Q}_{3}: 23.3 \mu \mathrm{g} / \mathrm{mL}\right)$. Due to limited funding, validation of the test used in the study was not performed in order to compare it to other manufacturers' tests. For the same reasons, a duplicate determination of $\mathrm{sCD}_{3} 6$ concentration was performed only for some blood samples. The precision of intra-assay and inter-assay in used ELISA was not determined by the manufacturer either. The range of plasma sCD36 concentrations $(7.14-78.9 \mu \mathrm{g} / \mathrm{mL})$ measured with the use of the kit was much higher than described in 2 previous studies. One of them [15] reported plasma sCD36 in healthy Caucasian subjects in the range of 20.0-45.0 ng/mL, while the other [16] reported $0.05^{-250} \mathrm{ng} / \mathrm{mL}$ plasma $\mathrm{SCD}_{3} 6$ in 10 undefined subjects. Significant differences in plasma $\mathrm{sCD}_{3} 6$ concentrations measured by 2 commercial ELISA: Adipobioscience and Cusabio Biotech sCD36 assays were also reported recently [17]. The first assay measured 10 samples in the range $0-250 \mathrm{ng} / \mathrm{mL}$, while the other measured the same 10 samples in the range 0.05-1.0 ng/mL. Only one study [18] - with obese diabetic Australian individuals - determined the absolute levels of sCD36 protein in the plasma samples to range from undetectable to as high as $22.9 \mu \mathrm{g} / \mathrm{mL}$. Unlike all other authors $[6,12,14$, $19,20]$ only relative or arbitrary units of $\mathrm{sCD}_{3} 6$ concentration were reported in the study. This limitation may be a major cause of inconsistent results of different studies concerning sCD36 and prevents the comparison of the data reported by the various authors. Moreover, there are several other possible explanations for significant differences between results obtained during measurements of concentration of sCD36 in plasma reported by several authors with range from $\mathrm{ng} / \mathrm{mL}$ to $\mu \mathrm{g} / \mathrm{mL}$. The differences may have originated from differences in patient population, different sources of tissue, differences in antibody specificity, or differences between the structure of the protein used as a standard and native sCD36 molecule found in the plasma.

One of the possible causes for the high concentration of sCD36 in the plasma samples may be the presence of platelets, but it seems that in our study residual cells and platelets were effectively removed from plasma at the centrifugation step (4000 g for $10 \mathrm{~min}$ ). Other authors [21] prepared platelet-free plasma by serial double centrifugation of fresh blood samples at $3000 \mathrm{~g}$ for $15 \mathrm{~min}$ at room temperature and isolated circulating $\mathrm{sCD}_{3} 6$ from platelet-free plasma by immunoprecipitation. The cited study established that more than $90 \%$ of circulating microparticles are thought to be platelet derived present in the plasma of normal healthy individuals. The second possible cause for the high concentration of $\mathrm{SCD}_{3} 6$ in plasma samples may be the presence or absence of various stimuli of $\mathrm{CD}_{3} 6$ expression. sCD36 is not subject to post-translational modification. The small size of our study group does not allow us to draw advanced conclusions, but it is necessary to identify possible problems in $\mathrm{sCD} 36$ plasma concentration measurement.

\section{CONCLUSIONS}

To conclude, it is crucial to standardize the methods of plasma $\mathrm{sCD} 36$ determination in further research before using sCD36 concentration as a potential risk factor of metabolic syndrome. 
ELISA can be one of the methods of plasma sCD36 determination. However, presented data suggest that $\mathrm{sCD}_{3} 6$ as a marker is difficult to evaluate, because the inter-relationship of sCD36 and various stimuli can significantly affect $\mathrm{sCD} 36$ plasma concentration.

\section{REFERENCES}

1. Tontonoz P, Nagy L, Alvarez JG, Thomazy VA, Evans RM. PPAR $\gamma$ promotes monocyte/macrophage differentiation and uptake of oxidized LDL. Cell 1998;93(2):241-52. doi: 10.1016/S0092-8674(00)81575-5.

2. Nicholson AC, Frieda S, Pearce A, Silverstein RL. Oxidized LDL binds to CD36 on human monocyte-derived macrophages and transfected cell lines: evidence implicating the lipid moiety of the lipoprotein as the binding site. Arterioscler Thromb Vasc Biol 1995;15(2):269-75. doi: 10.1161/01.ATV.15.2.269.

3. Nakagawa T, Nozaki S, Nishida M, Yakub JM, Tomiyama Y, Nakata A, et al. Oxidized LDL increases and interferon- $\gamma$ decreases expression of CD36 in human monocyte-derived macrophages. Arterioscler Thromb Vasc Biol 1998;18(8):1350-7. doi: 10.1161/01.ATV.18.8.1350.

4. Huh HY, Pearce SF, Yesner LM, Schindler JL, Silverstein RL. Regulated expression of CD36 during monocyte to macrophage differentiation: potential role of CD36 in foam cell formation. Blood 1996;87(5):2020-8.

5. Collot-Teixeira S, Martin J, McDermott-Roe C, Poston R, McGregor JL. CD36 and macrophages in atherosclerosis. Cardiovasc Res 2007;75(3):468-77. doi: 10.1016/j.cardiores.2007.03.010.

6. Tuomisto TT, Riekkinen MS, Viita H, Levonen AL, Yla-Herttuala S. Analysis of gene and protein expression during monocyte-macrophage differentiation and cholesterol loading - cDNA and protein array study. Atherosclerosis 2005;180(2):283-91. doi: 10.1016/j.atherosclerosis.2004.12.023.

7. Love-Gregory L, Sherva R, Schappe T, Qi JS, McCrea J, Klein S, et al. Common CD36 SNPs reduce protein expression and may contribute to a protective atherogenic profile. Hum Mol Genet 2011;20(1):193-201. doi:10.1093/ hmg/ddq449.

8. Libby P. Inflammation in atherosclerosis. Nature 2002;420:868-74. doi: 10.1038/nature01323.

9. Nicholson AC, Febbraio M, Han J, Silverstein RL, Hajjar DP. CD36 in atherosclerosis. The role of a class B macrophage scavenger receptor. Ann N Y Acad Sci 2000;902:128-31. doi: 10.1111/j.1749-6632.2000.tb06307.x.

10. Fernández-Real JM, Handberg A, Ortega F, Højlund K, Vendrell J, Ricart W. Circulating soluble CD36 is a novel marker of liver injury in subjects with altered glucose tolerance. J Nutr Biochem 2009;20(6):47784. doi: 10.1016/j.jnutbio.2008.05.009.

11. Handberg A, Norberg M, Stenlund H, Hallmans G, Attermann J, Eriksson JW. Soluble CD36 (sCD36) clusters with markers of insulin resistance, and high sCD36 is associated with increased type 2 diabetes risk. J Clin Endocrinol Metab 2010;95(4):1939-46. doi: 10.1210/jc.2009-2002.

12. Koonen DP, Jensen MK, Handberg A. Soluble CD36- a marker of the (pathophysiological) role of CD36 in the metabolic syndrome? Arch Physiol Biochem 2011;117(2):57-63. doi: 10.3109/13813455.2010.543136.

13. Glintborg D, Højlund K, Andersen M, Henriksen JE, Beck-Nielsen H, Handberg A. Soluble CD36 and risk markers of insulin resistance and atherosclerosis are elevated in polycystic ovary syndrome and significantly reduced during pioglitazone treatment. Diabetes Care 2008;31(2):32834. doi: $10.2337 / \mathrm{dc07}-1424$

14. Handberg A, Levin K, Højlund K, Beck-Nielsen H. Identification of the oxidized low-density lipoprotein scavenger receptor CD36 in plasma: a novel marker of insulin resistance. Circulation 2006;114(11):1169-76. doi: 10.1161/CIRCULATIONAHA.106.626135.

15. Chmielewski M, Bragfors-Helin AC, Stenvinkel P, Lindholm B, Anderstam B. Serum soluble CD36, assessed by a novel monoclonal antibody-based sandwich ELISA, predicts cardiovascular mortality in dialysis patients. Clin Chim Acta 2010;411:2079-82. doi: 10.1016/j.cca.2010.09.009.

16. Lykkeboe S, Larsen AL, Handberg A. Lack of consistency between two commercial ELISAs and against an in-house ELISA for the detection of CD36 in human plasma. Clin Chem Lab Med 2012;50(6):1071-4. doi: 10.1515/ cclm-2011-0950.

17. Handberg A, Højlund K, Gastaldelli A, Flyvbjerg A, Dekker JM, Petrie J, et al. Plasma sCD36 is associated with markers of atherosclerosis, insulin resistance and fatty liver in a nondiabetic healthy population. J Intern Med 2012;271(3):294-304. doi: 10.1111/j.1365-2796.2011.02442.x.

18. Alkhatatbeh MJ, Enjeti AK, Acharya S, Thorne RF, Lincz LF. The origin of circulating CD36 in type 2 diabetes. Nutr Diabetes 2013;3:e59. doi: 10.1038/nutd.2013.1.

19. Liani R, Halvorsen B, Sestili S, Handberg A, Santilli F, Vazzana N, et al. Plasma levels of soluble CD36, platelet activation, inflammation, and oxidative stress are increased in type 2 diabetic patients. Free Radic Biol Med 2012;52(8):1318-24. doi: 10.1016/j.freeradbiomed.2012.02.012.

20. Handberg A, Skjelland M, Michelsen AE, Sagen EL, Krohg-Sørensen K, Russell D, et al. Soluble CD36 in plasma is increased in patients with symptomatic atherosclerotic carotid plaques and is related to plaque instability. Stroke 2008;39(11):3092-5. doi: 10.1161/STROKEAHA.108.517128.

21. Alkhatatbeh MJ, Mhaidat NM, Enjeti AK, Lincz LF, Thorne RF. The putative diabetic plasma marker, soluble CD36, is non-cleaved, non-soluble and entirely associated with microparticles. J Thromb Haemost 2011;9(4):84451. doi: 10.1111/j.1538-7836.2011.04220.x. 